\title{
Cognition and Volition Impairment in \\ Criminal Conduct: A Look into the Application of the $\mathrm{M}^{\prime} \mathrm{Naghten}$ Test in Kenya
}

\author{
Muoki Ndunge*
}

\begin{abstract}
The M'Naghten test of insanity is applied in many common law countries including Kenya. It provides that to be legally insane, one must prove that the act or omission came from a disease of the mind that restricted someone from knowing what they are doing, and whether what they are doing is right or wrong in law. These requirements focus on the cognitive aspect of committing a crime. However, there exist cases where the accused commits an action based on an irresistible impulse that makes them unable to refrain from doing a certain action. This amounts to volitional impairment. Cognition and volition are important aspects to consider when evaluating legal insanity as a defence. This study seeks to explain the need for cognition and volition to be considered in the defence of insanity by describing the requirements of the M'Naghten rules with the objective to show its ignorance of the volitional aspect. Additionally, the study will delve into the need for both cognition and volition by expounding on what they entail and showing their application through the Model Penal Code test. Therein, the study will propose the use of the Model Penal Code test as a substitute for the M'Naghten rules applied in Kenya since it recognises the presence of both cognition and volition when committing a crime.
\end{abstract}

Key words: M’Naghten rules, cognition, volition, model penal code test, insanity.

\section{Introduction}

A general principle in Kenyan criminal law is that a person is not criminally liable for an offence unless it is proven by concrete evidence that they committed the offence, or omitted to act, voluntarily and with a blameworthy mind; hence the

The author is an LL.B student at the Strathmore University Law School in Nairobi, Kenya. 
maxim actus non facit reum, nisi mens sit rea. ${ }^{1}$ For an offence to be constituted, two elements must be present. First, the actus reus which is either the act, deed, commission, or omission. ${ }^{2}$ Second is the mens rea, which means the state of the mind of the accused which varies according to the type of offence. ${ }^{3}$

However, defences are available to help the accused negate or mitigate criminal responsibility. ${ }^{4}$ One such defence is insanity. The defence of insanity touches on the mens rea of the crime committed, which constitutes cognitive impairment and/or volitional impairment. Cognitive impairment refers to the lack of understanding and appreciation of the wrongfulness of an act. ${ }^{5}$ It is the basis of insanity tests such as the M'Naghten rules. Most jurisdictions tend to use cognitive impairment as the basis for determining insanity because it is easier to prove that a person was unable to comprehend the wrongfulness of their action based on the individual's mental health, hospital records and behaviour, than it is to prove a lack of self-control that occurred momentarily. ${ }^{6}$ Additionally, the consideration of cognitive impairment as a basis for insanity is a narrow and strict rule which ensures that only a mental illness that can be ascertained through records is considered under criminal law to negate criminal responsibility through the defence of insanity. ${ }^{7}$ This only allows the use of the defence of insanity for recognised severe mental illnesses thereby excluding the probability of the court considering an irresistible impulse to act.

The evolution of psychiatry has ushered in data that shows that some mental illnesses are linked to an inability to refrain. ${ }^{8}$ Volitional impairment therefore refers to a defect of control or an inability to refrain from committing certain actions. Hence there is need to acknowledge the presence of volition when certain criminal acts are committed. The importance of the free will in criminality can be traced back to Aristotle. From Aristotle's analysis in the Nicomachean ethics, involuntary actions are those that stem from actions owing

\footnotetext{
The maxim as defined by Lord Hailsham means that 'an act does not make a man guilty of crime unless his mind is also guilty.' Card R, Criminal law, 20 ed, Oxford University Press, Oxford, 2012, 34. See also Section 11, 12, Penal Code (Act no. 81 of 1948).

Musyoka W, Criminal law, Law Africa, Nairobi, 2013, 27.

Smith H and Brain H, Criminal law, 13ed, Oxford University Press, Oxford, 2011, 301.

Musyoka W, Criminal law, 105.

Parsons v State (1886), The Texas Court of Criminal Appeals.

Denno D, 'A mind to blame: New views on involuntary acts' 20 (5) Behavioural Science Law, 2003, 601-618.

Morse S, 'Causation, compulsion, and involuntariness' 22(2) Psychiatry Law, 1994, 159-80.

8 Noffsinger S and Resnick P, 'Insanity defence evaluations. Directions in Psychiatry' 19(1) Journal of Forensics, 1999, 325-338.
} 
to ignorance or actions under compulsion. ${ }^{9}$ Therefore, one could commit an act where they don't understand the wrongfulness of the conduct which amounts to cognitive impairment. Alternatively, one could commit an act because of an inability to refrain which translates to volitional impairment.

Aristotle's view on dual causality of involuntary actions resulted in various early English writers and courts adopting the same stand. ${ }^{10}$ In the early thirteenth century, Bracton became the first medieval jurist to address the topic of insanity and crime. ${ }^{11} \mathrm{He}$ observed that the will and purpose form distinct marks of crimes. Adapting Bracton's stance, William Lambard propounded that there is no significance in punishing the mad man who has no will and mind to serve punishment for committing a crime. ${ }^{12}$

British commentators such as Hale and Hawkins would affirm this position by ascertaining cognitive impairment as significant only to the extent that cognition bears upon the capacity to freely exercise one's will. ${ }^{13}$ Hale further ascertained the subsidiary nature of cognitive deficiency by emphasising that man is endowed with two faculties, understanding and liberty of will. ${ }^{14}$ The liberty or choice of the will presupposes an act in which the will understands the action. Therefore, where there is a total defect of understanding, there is no free will to act. Consequently, making both cognitive and volitional impairment important is ascertaining criminal responsibility.

Hawkins went on further to illustrate the injustice that would be occasioned when actions of both cognitive and volitional impairment were criminalised. ${ }^{15}$ He ascertained that the criminality of an act supposes a wilful disobedience to law. ${ }^{16}$ This can only apply to those who are capable of understanding the act and conforming themselves to it. Therefore, it would be unjust to find one criminally responsible for an act that the person does not understand.

Blackstone Commentaries additionally recognise the importance of volitional impairment by reducing all forbidden acts to one single consideration,

9 Aristotle, The Nicomachean ethics, 15ed, Oxford University Press, Oxford, 2009. Translated by David Ross and edited by Lesley Brown.

10 Crotty H, 'The history of insanity as a defence to crime in English criminal law' 12(1) California Law Review, 1924, 113-115.

11 Henri B, On the lawes and customs of England, 4ed, Belkap Press, London, 1968, 375. Translated by Samuel Thorne.

12 Hale M, A history of the pleas of the crown, Philadelphia Press, Philadelphia, 1762, 13-14.

13 Crotty $\mathrm{H}$, 'The history of insanity as a defence to crime in English criminal law', 113-115.

14 Crotty $\mathrm{H}$, 'The history of insanity as a defence to crime in English criminal law', 113-115.

15 Hale M, $A$ bistory of the pleas of the crown, 13-14.

16 Hale M, $A$ history of the pleas of the crown, 13-14. 
the want or defect of the will. ${ }^{17}$ Consequently, the volitional aspect of a criminal act bears a heavy weight on criminal responsibility. However, many countries apply the M'Naghten test that only recognises the cognitive aspect of a criminal act. This begs an inquiry as to why.

Volitional impairment has taken a back seat, not based on serious policy considerations of justice but rather the unrelenting opinion of the public on the defence of insanity and its broadness when it includes the inability to control one's will. ${ }^{18}$ This view arose from the M'Naghten and Hinckley cases. ${ }^{19}$ The two cases occurred in two different jurisdictions (the latter in United States of America and the former in the United Kingdom) at two very separate times in history but with the same effect of the law surrendering itself to the public. In both cases, there was ample evidence that both men suffered from delusions which severely impaired their abilities to reason. M'Naghten's delusions were centred on unfounded fears that he was being persecuted by Queen Victoria's government whereas Hinckley's delusion involved a linked relationship between assassinating President Reagan and earning the love of an unattainable movie star. Both men therefore depicted strong mental diseases that required the court to acquit them. However, both courts faced overwhelming criticism for the acquittals. ${ }^{20}$ Consequently, in the aftermath of both cases, the substantive test of insanity was changed by the abolition of any provision requiring volitional impairment to negate criminal responsibility. ${ }^{21}$

Law and society are imperative to each other's existence. However, this does not mean that law should conform to the ever-changing tides of public opinion. ${ }^{22}$ Law should serve not only the wants of what we conceive from time to time to be our immediate material needs but also certain enduring values. ${ }^{23}$ The establishment of the rigid cognitive test (M'Naghten) does not reflect this, as it is unjust to banish those who speak in voices that are too faint to be heard by society's demand of punishment. ${ }^{24}$

\footnotetext{
17 Crotty H, 'The history of insanity as a defence to crime in English criminal law', 113-115.

18 English J, 'The light between twilight and dusk: Federal criminal law and the volitional insanity defence' 40(1) Hastings Law Journal, 1988, 8.

19 Republic v M'Naghten (1843), The United Kingdom House of Lords. See also Republic v Hinckley (1998), United States Court of Appeal.

20 Perlin M, 'Book review of the insanity defence and the trial of John W. Hinckley, Jr., by Lincoln Caplan' 30 (1) New York Law Review, 1985, 859.

21 English J, 'The light between twilight and dusk: Federal criminal law and the volitional insanity defence', 8.

22 Bickel A, The least dangerous branch, Bobbs-Merril publishers, New York, 1962, 24.

23 Bickel A, The least dangerous branch, 24.

${ }^{24}$ McCleskey v Kemp (1987), The United States Supreme Court. Dissenting opinion of Bremnan J.
} 
In Kenya, the defence of insanity is provided for in Sections 11 and 12 of the Penal Code which give the accused the burden of raising the defence of insanity and proving it. ${ }^{25}$ However, the court must still ascertain legal insanity using a test. The provisions of the Kenyan Penal Code allow for the use of the M'Naghten rules as the test for ascertaining legal insanity. ${ }^{26}$ The M'Naghten rules require the accused to prove that they had a disease of the mind, which impaired them from knowing what they were doing and if their actions were wrong or right in the eyes of the law. ${ }^{27}$ However, the M'Naghten rules as seen above only acknowledge the cognitive aspect of one's mind. ${ }^{28}$ Nonetheless, there are cases in which the accused commits a crime on an irresistible impulse limiting selfcontrol of their actions. When this occurs, it becomes difficult for courts to apply the M'Naghten rules, as they do not extend beyond the realm of volition. Consequently, this brings about the question of how Kenyan courts seek to deal with crimes committed based on volition using the M'Naghten rules.

This study seeks to answer whether insanity tests that are based on the cognitive aspects only are sufficient in determining legal insanity. This will be done using case law, literature review and a comparative study of the M'Naghten rules and the Model Penal Code test. This study is divided into four parts. Part I acts as the introduction that will focus on the definition, history and development of cognitive and volitional impairment in the defence of insanity. Additionally, part I will look at the development of the defence of insanity with special attention to the establishment of the M'Naghten rules that are applied in Kenya. Part II will look at the practice in Kenya of using the M'Naghten rules even when they do not cater for volitional impairment and will present the Model Penal Code test that recognises both cognitional and volitional impairment as a solution to the shortcomings of the M'Naghten rules. Part III will provide for a specific application of the Model Penal Code test in Kenya in a way that does not take away from the M'Naghten rules but adds onto it. The study will then conclude in Part IV.

\footnotetext{
Musyoka W, Criminal law, 105.

26 Ghai $\mathrm{Y}$ and McAuslan J, Public law and political change in Kenya: A study of the legal framework of government from colonial times to present, Oxford University Press, New York, 1970.

27 Section 12, Penal Code (Act No. 81 of 1948).

28 Fuller R, 'A philosophical critique of cognitive psychology's definition of the person' 4(1) The Pluralist, 2009, 96. Wherein cognitive means the thought process of the accused.
} 


\section{i. Legal insanity}

The defence of insanity was developed from the M'Naghten case. ${ }^{29}$ Daniel M'Naghten was charged with the murder of Edward Drummond. The accused pulled out a loaded pistol and shot Mr. Edward Drummond. During the trial, it was deduced that M'Naghten was under the deluded belief that Mr Drummond was working with the prime minister to kill him. ${ }^{30}$ This case led to lengthy deliberations on how to establish whether an accused person is legally insane. ${ }^{31}$ The M'Naghten rules were then born, consisting of three requirements which are elaborated below. ${ }^{32}$

The first requirement is that the accused must prove that at the time of commission or omission of the act they were labouring under a defect of reason arising from a disease of the mind. A disease of the mind is one recognised as a mental disorder according to psychiatry. The most commonly known are: schizophrenia, depressive disease and psychopathy. A disease of the mind can stem from a physical cause that affects the brain and may restrict blood flow. ${ }^{33}$

Secondly, the accused must prove that he was incapable of understanding what he was doing or that he was incapable of knowing what he was doing was wrong before the law. ${ }^{34}$ This requirement forms the principal aspect of the M'Naghten test and is divided into two parts. The first is the incapacity to know what one is doing and the second is the incapacity to know that what one is doing is wrong before the law. Under the first provision, the accused must show that at the time the crime took place they were unable to appreciate what they were doing and the implications it would bring. ${ }^{35}$ The distortions created by a disease of the mind are often so extreme that one may do something believing it is something else. ${ }^{36}$ The person may know that they are doing something but not fully comprehend and appreciate the exact nature and magnitude of what they are doing. ${ }^{37}$ In the case of $R v$ Clarke this incapacity was deemed to apply

\footnotetext{
Republic $v$ M'Naghten (1843), The United Kingdom House of Lords.

Republic v M'Naghten (1843), The United Kingdom House of Lords. Mr. Drummond was the then secretary of the Prime minister.

31 Kaplan J, Weisberg R and Binder G, Criminal Law: Cases and materials, 5ed, Aspen Publishers, New York, 2004, 585.

32 Card R, Criminal Law, 609.

33 Musyoka W, Criminal law, 106.

34 Republic v M'Naghten (1843), The United Kingdom House of Lords.

35 Smith $\mathrm{H}$ and Brain $\mathrm{H}$, Criminal law, 301.

36 Parsons v State (1886), The Texas Court of Criminal Appeals.

37 Card R, Criminal Law, 614.
} 
only when the power of reasoning is absent to the extent that the accused cannot understand what they are doing. ${ }^{38}$

The second incapacity deals with the parameters of what defines 'wrong'. The accused must prove that at the time of the crime they did not know that what they were doing was wrong before the law. ${ }^{39}$ The test used to illustrate the above is the reasonable man test. The court ascertains whether the accused at the time knew, by the standard applied to a reasonable man, that what he or she was doing was wrong or right according to law. ${ }^{40}$ Furthermore, this belief must be based on adduced evidence. ${ }^{41}$

In $R v$ Windle the judge laboured to define what 'wrong' in this case of incapacity means. ${ }^{42} \mathrm{Mr}$. Windle was convicted of the murder of his wife. He was married to a woman who was eighteen years older than him and he could be termed a 'weak character'. His wife constantly talked about committing suicide. Consequently, Windle became so obsessed with suicide that he talked about it at work. By asking his colleagues what he could do to help his wife commit suicide, his co-workers got tired of him and out of frustration one of them replied 'give her 100 aspirins'. The next day the accused gave his wife 100 aspirins leading to her death. ${ }^{43}$ It was determined that this was a form of communicated insanity known as folie a deux, which arises when a person is in constant attendance of someone who is of unsound mind. ${ }^{44}$ The court agreed that the accused did suffer from a disease of the mind but he knew what he was doing was wrong.

38 Regina v Clarke (1972), The United Kingdom House of Lords. The accused selected various items in a supermarket and put them into a wire basket. Before she went to check out her shopping, she removed three items and placed them inside her bag. She then proceeded to the check out. These three items were, therefore, not paid for. She was charged with stealing the items. During the trial the accused raised the defence of insanity. From the evidence availed, it was deduced that the accused suffered from diabetes and had domestic issues. Furthermore, she was suffering from depression. Her psychiatrist testified that depression could lead to periods of absent-mindedness in rare cases, and that her current medical and home situation affected her judgement. The courts held that the accused could not fit the standard of insanity as the effects of her mental illness did not correspond with her act. This implied that her absent-mindedness did not stem from her disease but was a moment in which she failed to use her power of reasoning.

Musyoka W, Criminal law, 108. The reasonable man test, according to the McQuire case is a man on a clapham bus which is a commonly used bus in England. Therefore, the reasonable man is the normal person on a bus.

41 Musyoka W, Criminal law, 108.

${ }^{42}$ Regina $v$ Windle (1952), The United Kingdom House of Lords.

43 Regina $v$ Windle (1952), The United Kingdom House of Lords.

44 Patel K, Adam S and Suzanna H, 'Case report of shared psychotic disorder of folie a deux in two geriatric sisters' 1(1) West Virginia Medical Journal, 2017, 1. Folie a deux is a disorder characterised by transfer of delusional beliefs from one person, the primary patient, to another, the secondary patient, who are closely related. 
Accordingly, he had chosen to kill his wife out of sympathy and kindness to alleviate her suffering. Judge Goddard went on to show the difference between what amounts to 'wrong' under the law and under morality;

'The argument in this appeal has been concerned with what is meant by the word 'wrong'. The counsel for the appellant suggested that wrong as used in the M'Naghten rules did not mean contrary to law but had some qualified meaning -morally wrong- and that if someone was in a state of mind through a defect of reason that he thought that what he was doing, although he knew it was wrong in law, was really beneficial, or kind, or praiseworthy, that would excuse him. Courts of law, however, can only distinguish between that which is in accordance with the law and that which is contrary to the law. There are many acts which, we all know, to use an expression found in some old cases, are contrary to the law of God and man. In the Decalogue are the commandments: 'Thou shall not kill' and 'Thou shall not steal'. Such acts are contrary to the law of man and they are contrary to the law of God. With regard to the Seventh Commandment: 'Thou shall not commit adultery', it will be found that, so far as the criminal law is concerned, though that act is contrary to the law of God, it is not contrary to the law of man'. ${ }^{45}$

Therefore, wrong can only mean what is contrary to the law and not what is morally wrong. Whether the accused sought to alleviate the victim's pain and suffering, thereby acting out of kindness, does not stand as a defence under insanity. ${ }^{46}$

The third aspect of the M'Naghten rules is insane delusion, also known as partial insanity. ${ }^{47}$ It refers to an insane belief that cannot be eradicated from the person's mind by way of reasoning. ${ }^{48}$ The rule in insane delusions is that the person suffering from them should be treated as being in the same position of responsibility as if the facts, with respect to which the delusions exist, are real. ${ }^{49}$ Take for example a case where D thinks A wants to kill him, even though A is silently sitting across from D. D is deluded into thinking that A wants to kill him and attacks him. D therefore reacts to this delusion and proceeds to kill $\mathrm{A}$ in 'self-defence'. D in the state of his delusion would be justified in killing A and would be found guilty but insane. ${ }^{50}$ It has been argued that this aspect of the rule is redundant. Generally, it is regarded as a mere restatement of the principal

\footnotetext{
Regina $v$ Windle (1952), The United Kingdom House of Lords.

Smith $\mathrm{H}$ and Brian H, Criminal Law, 422.

47 Nyasani JM, Legal philosophy: Jurisprudence, Consolata Institute of Philosophy Press, Nairobi, 2001, 69.

48 Musyoka W, Criminal law, 109.

49 Card R, Criminal Law, 616.

50 Card R, Criminal Law, 616.
} 
aspect of the M'Naghten test. ${ }^{51}$ Thus, this statement is almost always ignored by the courts, Kenyan courts included. ${ }^{52}$

\section{The Practice in Kenyan Courts}

The courts follow the provisions of the M'Naghten rules as stated in the Penal Code. ${ }^{53}$ One needs to first prove that the accused is suffering from a disease of the mind that impairs his or her judgment. ${ }^{54}$ Therefore, the accused cannot discern what he or she is doing and whether it is right or wrong in law. ${ }^{55}$ In the case of Richard Kaitany $v$ Republic, ${ }^{56}$ the court went to great lengths to determine whether the accused was legally insane. Mr. Richard Kaitany had killed the deceased in a brutal manner.

During the trial, the judge received evidence that the accused had once been admitted to Mathare Mental Hospital for a few months due to epilepsy. This showed the existence of a disease of the mind that had, on many occasions, impaired the accused's judgement. Additionally, it was also proven that the accused was a constant drinker and had taken up bhang. Both of these had an adverse effect on his already strained mental capabilities. Additionally, input from an expert psychiatrist showed that the accused was not in his right state of mind at the time of the crime. Further, he did not know what he was doing and the implications this had in law. Ironically, he admitted to knowing what he was doing was wrong at the time of the crime.

The accused was suffering from epilepsy, which is not considered a mental disease amounting to legal insanity, unless during the fit the accused harms someone. This would amount to automatism, where 'an act is done by the muscles without any control by the mind (such as a reflex action, or a spasmodic or convulsive act) if it is done during a state involving a loss of consciousness'. ${ }^{57}$ This was not the case since the accused at the time of the crime was not suffering from an epileptic seizure but the remnants of the side effects. The court laboured

\footnotetext{
51 Card R, Criminal Law, 616. The principal aspect is whether the accused knew what they were doing and furthermore, whether they knew what they were doing is wrong in law.

52 Smith $\mathrm{H}$ and Brian $\mathrm{H}$, Criminal law, 304.

53 Section 12, Penal Code (Act No. 81 of 1948).

54 Section 12, Penal Code (Act No. 81 of 1948).

55 Card R, Criminal Law, 614.

56 Richard Kaitany Chemagong v Republic (1984) eKLR.

57 Card R, Criminal Law, 614.
} 
and found the accused legally insane even though he knew his actions and knew it was wrong in the eyes of the law, thereby not satisfying the M'Naghten rules. This begs the question; what insanity test then did the courts apply?

The shortcomings of the M'Naghten rules from the above case are clear. Over-reliance on only the offender's knowledge of committing an action and its wrongfulness yields unjustified rulings. If the court had considered that the accused was a frequent bhang taker, it would have been easy to understand that he may have been compelled to act as he had, due to a hallucination, and was therefore unable to refrain from acting, which would lead the court to consider volitional impairment to determine the insanity of the accused. Consequently, in the section below the study will look into volition and cognition impairment as a basis for any insanity test. This will be through the Model Penal Code test.

\section{i. The Model Penal Code test}

The Model Penal Code test provides that:

i) A person is not responsible for criminal conduct if, at the time of such conduct, because of a mental disease or defect, he lacks substantial capacity either to appreciate the criminality of his conduct, or to conform his conduct to the requirements of the law;

ii) The terms 'mental disease or defect' mentioned above do not include an abnormality manifested only by repeated criminal or otherwise antisocial conduct. ${ }^{58}$

The above test varies from the M'Naghten test in the following ways: it introduces the word 'appreciate' to substitute 'know,' which covers the emotional aspect of mental incapacity as well as the intellectual; using the word 'conform', the rule divests itself of historical baggage, eliminating implications of the irresistible impulse; through requiring substantial incapacity, it eliminates the risk implicit in older cases, where there was a requirement for complete destruction of the accused's mental capacity. ${ }^{59}$ The rule was warmly welcomed as a replacement of the M'Naghten rules as rightly put by Judge Haynsworth:

'With appropriate balance between cognition and volition, it demands an unrestricted inquiry into the whole personality of an accused who surmounts the threshold question of doubt of his responsibility. Its verbiage is understandable by psychiatrists; it imposes no limitation upon the testimony and yet, to a substantial extent, it avoids a diagnostic

\footnotetext{
Section 4.01, Model Penal Code (The United States of America).

59 Kaplan J et al, Criminal law, 599.
} 
approach and leaves the jury free to make its findings in terms of a standard which society prescribes and the jury applies'. ${ }^{60}$

The model penal code, therefore, provides a test that recognises cognitional and volitional impairment when committing crime. Insanity when only proven on the cognitive aspect while the volition aspect of the action is ignored can result in unjust rulings such as the case of Grace Nyoroka v Republic, ${ }^{61}$ where the accused was convicted based on only cognitive aspects and failed to get adequate treatment for her volitional impairment. Consequently, it appears that the courts stretch the M'Naghten rules into realms it cannot cover. To solve this the author proposes the adaptation of the Model Penal Code test in Kenya.

\section{Recommendations}

The author is of the view that the Model Penal Code test should be adopted by Kenyan law. With a growing number of people in Kenya facing psychological issues, there has been exceptional growth of the psychiatric profession. ${ }^{62}$ Furthermore, since 1843, the world of mental health has expanded to include new illnesses and fields. ${ }^{63}$ Therefore, it would be counterproductive to still use the same old rules applied to an evolved field.

The Model Penal Code provides for both the cognitive and volitional aspect of insanity. ${ }^{64}$ Thus, it does not take away the M'Naghten rules but adds to them. It is in this stead that the author recommends an amendment to Section 12 of the Penal Code from the following:

'A person is not criminally responsible for an act or omission if at the time of doing the act or making the omission he is through any disease affecting his mind incapable of understanding what he is doing, or of knowing that he ought not to do the act or make the omission; but a person may be criminally responsible for an act or omission, although his mind is affected by disease, if such disease does not in fact produce upon his mind one or other of the effects above mentioned in reference to that act or omission'. ${ }^{65}$

\footnotetext{
60 United States $v$ Chandler (1968), The United States Court of Appeals.

${ }_{61}$ Grace Nyoroka v Republic (2007) eKLR.

62 Marangu, E, Sands N, Rolley J and Ndetei D, Mental healthcare in Kenya: Exploring optimal conditions for capacity building' 6(1) African journal of primary health care E family medicine, 2014, 1-2.

6.3 Sobeloff S, 'Insanity and the criminal law: From M'Naghten to Durham and beyond' 40(9) American Bar Association Journal, 795.

${ }^{64}$ Bonnie R, Coughlin A, Jeffries J and Low P, Criminal law, 4 ed, Foundation Press, St. Paul, 538.

65 Section 12, Penal Code (Act No. 81 of 1948).
} 
To the following:

'A person is not criminally responsible for an act or omission if at the time of doing the act or making the omission the person lacked substantial capacity due to a disease of the mind either to appreciate the criminality of his conduct or to conform his conduct to the requirements of the law; the disease of the mind is not inclusive of abnormality manifested only by repeated criminal or otherwise antisocial behaviour'.

The amendment would encompass the aspect of volition due to the word 'appreciate' instead of 'knowing', as appreciate entails recognition of emotional incapacity that refrains one from acting as well as an intellectual deficiency to understand the wrongfulness of the act. ${ }^{66}$ Through this, the courts will be able to provide adequate care for those found guilty but insane on an impulse or lack of self-control stemming from a mental disease. In this way, a mentally ill person does not go to prison, since what they require is rehabilitation, just because the law has yet to recognise the influence of volition in mental health issues. As rightly put:

'The full merit of the New Hampshire decision (development of the Model Penal Code test) is precisely that it does not attempt to embody one set of medical theories in place of another, for even if it were possible to frame a test embodying more modern knowledge there would still be the danger that in the progress of science the new rule itself might be found inadequate. The whole point is not to restrict the test to particular symptoms, but to permit as broad an inquiry as may be found necessary according to the latest accepted scientific criteria, ${ }^{67}$

\section{Conclusion}

From the above, it is noted that the defence of insanity in common law countries is accessible through the M'Naghten rules. In other jurisdictions, different rules such as the irresistible impulse test, the Durham test and the Model Penal Code test are used. In Kenya, the defence of insanity is available under Section 12 of the Penal Code, like the M'Naghten rules. For one to be found legally insane the accused must satisfy the requirements present in Section 12 of the Penal Code. These requirements are that, the accused must show that they were affected by a disease of the mind that impaired their reasoning. Thus, they were not able to know what exactly they were doing or distinguish if their act was right or wrong according to law. These two requirements only acknowledge

66 Kaplan J et al, Criminal law, 599.

67 Sobeloff S, 'Insanity and the criminal law: From M'Naghten to Durham and beyond', 795. 
the cognitive aspect of an act, consequently ignoring acts or omissions that occur due to volition. This lacuna in the law becomes evident when the Richard Kaitany Chemagong and Grace Nyoroka cases are discussed.

To fill this gap in the law, the author has suggested the use of the Model Penal Code test in Kenya as it acknowledges both cognition and volition. The test requires one to prove they were suffering from a mental defect that caused lack of substantial capacity to either appreciate the criminality of one's conduct or to conform their conduct to the requirements of law. Under this test, the term mental disease or defect does not apply to abnormalities manifested only by repeated criminal or otherwise antisocial conduct. The Model Penal Code test provides for volition with the introduction of the words 'substantial capacity', 'appreciate' and 'conform,' which introduce the prospect of impulses and emotions leading to a criminal act or omission. Consequently so, the author therefore advocates the use of the Model Penal Code test in order to fill in the gaps of the M'Naghten rules by recognising both cognitive and volitional impairment under the defence of insanity. 
